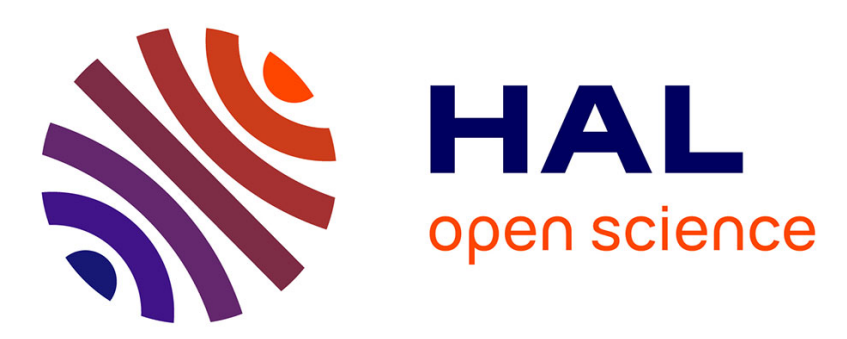

\title{
Moving to autarky, trade creation and home market effect: an exhaustive analysis of regional trade agreements in Africa
}

Fabien Candau, Geoffroy Guepie, Julie Schlick

\section{- To cite this version:}

Fabien Candau, Geoffroy Guepie, Julie Schlick. Moving to autarky, trade creation and home market effect: an exhaustive analysis of regional trade agreements in Africa. Applied Economics, 2019, 51 (30), pp.3293-3309. 10.1080/00036846.2019.1566691 . hal-02139357

\section{HAL Id: hal-02139357 \\ https://hal.science/hal-02139357}

Submitted on 29 Oct 2021

HAL is a multi-disciplinary open access archive for the deposit and dissemination of scientific research documents, whether they are published or not. The documents may come from teaching and research institutions in France or abroad, or from public or private research centers.
L'archive ouverte pluridisciplinaire HAL, est destinée au dépôt et à la diffusion de documents scientifiques de niveau recherche, publiés ou non, émanant des établissements d'enseignement et de recherche français ou étrangers, des laboratoires publics ou privés. 


\title{
Moving to Autarky, Trade Creation and Home Market Effect: an Exhaustive Analysis of Regional Trade Agreements in Africa
}

\author{
Fabien Candau, Geoffroy Guepieł Julie Schlick ${ }^{\ddagger}$ \\ Here a working paper version of the article published in Applied \\ Economics, 2019, 51(30), 3293-3309.
}

\begin{abstract}
This article analyzes the effects of Regional Trade Agreements (RTAs) on bilateral trade in Africa. A structural gravity equation is estimated over the period 1955-2014. The overall effect of RTAs on African trade is strong, but depending on the nature of the RTAs, there is a decreasing impact over time. While Economic Integration Agreements (EIAs) still favour trade in Africa, there was no trade creation coming from Free Trade Agreements between 1990 and 2014. However, the provisions of RTAs do not have a negative impact on trade: agreements that include behind-the-border policies do not significantly deter bilateral trade. To explain the declining impact of RTAs, we look at their redistributive impact between members states. There is no evidence that large countries disproportionally export diversified goods due to RTAs (no 'home effect'). Countries with a good international network ('hub effect') benefited more than other countries of RTAs between 1955 and 1990 but this is however less true on the most recent period (1990-2014).
\end{abstract}

JEL: F13, F15

Keywords: Trade diversion, HME, Hub effect, ECOWAS, COMESA

*UNIV PAU \& PAYS ADOUR, CATT, Av Poplawski, 64000 Pau. E-Mail: fabien.candau@univpau.fr

${ }^{\dagger}$ UNIV PAU \& PAYS ADOUR, CATT, Av Poplawski, 64000 Pau.

‡UNIV PAU \& PAYS ADOUR, CATT, Av Poplawski, 64000 Pau. 


\section{Introduction}

Africa seems to follow a different path in term of trade integration than the rest of the world: while trade integration is put into question in developed countries, African countries are still interested by Regional Trade Agreements (RTAs) as illustrated by the recent Tripartite Free Trade Area (TFTA) agreement that aims to create a freetrade zone stretching from Cape Town to Cairo. This may represent a turning point after years of trade integration, indeed African countries have enforced many different Regional Trade Agreements (RTAs) that differ in their degree of integration, going from free trade areas, ${ }^{1}$ to common markets $^{2}$, to custom unions ${ }^{3}$ and finally to monetary unions ${ }^{4}$.

Before to pursue this integration on a continental basis, it seems interesting to evaluate these agreements. As discussed by Melo and Tsikata (2015) and Hoekman and Njinkeu (2017) very few studies have analyzed African RTAs in depth. In comparison with the existing literature we propose to control of the long list of individual and bilateral variables that can explain the weak continental integration (specialisation patterns, regional or civil conflicts, preferential agreements with developed countries, etc) by using country pair, importer-year, and exporter-year fixed effects. All the aforementioned RTAs in Africa enforced between 1955 and 2014 are analyzed. To our knowledge, RTAs in Africa have never been studied for such a long period of time and with all these controls that allow to reduce the endogeneity bias of omitted variables.

We find that the effects of RTAs have been strong but the bulk of this trade creation occurred between 1955 and 1990. Regarding the nature of RTAs, while Economic Integration Agreements (EIAs) still favour trade in Africa, there was no trade creation coming from Free Trade Agreements between 1990 and 2014. In that period, when the heterogeneity of RTAs are taken into account, RTAs in general (EIAs and FTAs) have no effect. This lack of impact can have different causes, among which the content of the RTAs that has changed over time. Regional agreements such as ECOWAS, COMESA, WAEMU, EAC, or SADC include rules on capital mobility, competition and on environmental policies introducing hidden protection that may be detrimental for trade. For

\footnotetext{
${ }^{1}$ The Southern African Development Community (SADC)

${ }^{2}$ The Common Market for Eastern and Southern Africa (COMESA) and the East African Community (EAC)

${ }^{3}$ The Economic Community of West African States (ECOWAS)

${ }^{4}$ The West African Economic and Monetary Union (WAEMU) and the Economic and Monetary Community of Central Africa (CEMAC)
} 
instance, Kohl, Brakman and Garretsen (2016) find that RTAs with provisions going beyond the WTO's current mandate (e.g. capital mobility, competition, regulation of the labor market) reduce trade. As argued by Rodrick (2018) "free trade agreements" are less about "free trade" and more about behind-the-border policies (regulatory standards, investments, etc) driven by rent-seeking behavior of well-connected firms that lead to inefficient trade agreements. ${ }^{5}$ We contend that this hypothesis does not apply to Africa. RTAs that include behind-the-border policies do not significantly deter trade there.

Another reason explaining why contemporary RTAs have limited effects, may be found in their redistributive effects between members, improving the terms of trade of some countries at the expense of others. In relatively large countries, economies of scale due to the domestic market size may explain why RTAs have fostered the creation of a disproportionate numbers of activities in these countries and not elsewhere. In colloquial terms, this analysis refers to the literature on the "home market effect" (Krugman, 1980; Crozet and Trionfetti, 2008; Costinot et al., 2017). This theoretical hypothesis has not yet been tested for Africa since the continent is rightly viewed as being highly specialized on a limited number of agricultural goods. There are however some countries in Africa that may have attracted industrial activities in the way described by Krugman (1980). Beyond that effect, we also test the "hub effect hypothesis": with regional trade integration, a country with the best access to other markets can become a platform for exports, attracting and creating activities at the expense of countries with poor international networks (Puga and Venables, 1997; Ossa, 2011; Mossay and Tabuchi, 2015). Overall we find that there is no home market effect due to RTAs, however some hub effects are observed.

Regarding the literature on RTAs in Africa, only a handfull of studies have been undertaken with the aim to better control for bilateral and individual-time unobserved characteristics. Carrère (2004) provides convincing evidence of the positive effect of RTAs on african trade using a panel specification with random bilateral effects. In comparison in this study, unobserved time-invariant bilateral variables (affecting the probability of signing an RTA and/or directly the volume of trade) are taken into account with bilateral fixed effects. From an economic point of view, a gravity equation with fixed effects seems more suitable than with random effects assuming zero

\footnotetext{
${ }^{5}$ Bouet, Laborde and Martimort (2017) characterize how informational asymmetries explain behindthe-border policies and inefficient trade agreements.
} 
correlation between unobservables and RTAs. ${ }^{6}$ Furthermore, following Magee (2008), importer-year and exporter-year effects are used to control for institutional and cultural determinants of trade that vary over the period analyzed. Other studies devoted to Africa, do not use all these controls to resolve the endogeneity bias of omitted variables, work with a shorter period of time, with a smaller sample of countries, do not consider the provisions of RTAs, and rarely test trade theories. Finally we use a recent quantitative model of trade to assess the impact of no RTAs by simulating a counterfactual scenario moving African countries to autarky. This counterfactual exercise show that RTAs have impacted on trade costs, multilateral resistances and finally on trade flows but with small effects on welfare.

The remainder of the paper is organized as follows. In Section II, the baseline empirical evidence is presented. Section III discusses the main results in respect of trade creation. Section IV assesses the global potential effects of RTAs by considering trade diversion, home market and hub effects. Section $\mathrm{V}$ analyzes the individual gains of RTAs and the final section outlines the study's conclusions.

\section{Trade and Regional Trade Agreements in Africa}

\subsection{Empirical strategy}

From neoclassical models of trade with perfect competition to new trade theories with increasing returns to scale, many different models display a gravity equation that takes the following form:

$$
X_{o d}=\phi_{o d} \frac{Y_{o}}{\prod_{o}^{1-\sigma}} \frac{Y_{d}}{P_{d}^{1-\sigma}}
$$

where $\sigma$ is the elasticity of substitution between varieties $(\sigma>1), \phi_{o d}$ an inversed measure of trade costs (trade openness) between $o$ and $d, Y_{d}$ and $Y_{o}$ the aggregated expenditures/incomes at the destination of exports $d$ and at origin $o . \Pi_{o}^{1-\sigma}$ represents the market potential in $o$. This term is sometimes considered as an indicator of the market access from $o$ and/or called outward multilateral resistance because it represents a GDP share weighted measure of trade cost resistance that exporters in $o$ face when they ship their goods to consumers on their own and outward markets. Concerning

\footnotetext{
${ }^{6}$ From an econometric point of view, there are also arguments in the literature for the rejection of a random-effects gravity model (see Egger, 2000). Furthermore models with fixed effects take into account the multilateral frictions of trade that matter to explain bilateral exports (see Fally, 2015).
} 
african RTAs, this term may matter since the recent History of Africa (e.g. slavery, colonialism, preferential trade agreements ${ }^{7}$ ) has affected bilateral trade costs between african countries relatively to trade costs with distant countries. The term $P_{d}^{1-\sigma}$ in this gravity equation (1) is the accessibility-weighted sum of exporters- $O$ capabilities also called inward multilateral resistance since it is a reversed measure of the openness of a nation to import from the world. Anderson and Yotov (2010) also consider this term as the buyers' incidence because it represents the weighted sum of trade costs paid by buyers.

This gravity equation is estimated using the pseudo-maximum likelihood (PML) estimator as follows:

$$
X_{o d t}=\exp \left(\alpha+f_{o t}+f_{d t}+f_{t}+\phi_{o d t}+\epsilon_{o d t}\right)
$$

where $f_{o t}$ and $f_{d t}$ are time-varying countries-specific effects approximating exporting and importing capacity, $Y_{o, s} / \Pi_{o, s}^{1-\sigma_{s}}$ and $E_{d, s} / P_{d, s}^{1-\sigma_{s}}$ in Equation (1) at time $t, \alpha$ is a constant.

Subscripts $o$ and $d$ represent all countries in the world, we also define two subsets $i$ and $j$ that represent African countries respectively at the origin $o$ of the trade flow and at destination $d(i \in o, j \in d)$. RT $A_{i j t}$ takes 1 at the year $t$ when the regional agreement between African partners $i$ and $j$ enters into force and zero otherwise, $R T A_{i-d t}$ is a dummy taking value 1 if $i$ is a member of any RTA, which excludes $d$. Similarly, $R T A_{j-o t}$ takes 1 if importer $j$ has signed any other RTA with any outside trade partners. We also consider the nature of RTAs by distinguishing Free Trade Agreement (FTA) such as EAC and SADC and Economic Integration Agreements (EIA) such as CEMAC and WAEMU. Moreover, beyond these distinctions, RTAs differ also in terms of provision, institutional design and legal enforceability, we thus introduce the indices of trade agreement heterogeneity proposed by Kohl, Brakman and Garretsen (2016) to analyze which kind of RTAs is trade promoting.

To control for other bilateral relationships, binary bilateral variables are used i.e. dummies for colonial links, borders, common language and physical distance. Since this strategy raises doubts regarding the possibility of omitted variables, we compare results with estimations including bilateral fixed effects $f_{o d}$ to control for all unobserved

\footnotetext{
${ }^{7}$ The first Generalized System of Preferences were non-reciprocal schemes implemented by the European Economic Community and Japan in 1971 and by the USA in 1976, i.e. only a few decades after the wave of independances, to facilitate LDCs access to markets of rich countries. See Candau and Jean (2009) for a detailed analyzis on the utilisation of these trade preferences in Africa.
} 
time-unvarying bilateral determinants of exports (Baier and Bergstrand, 2007; Magee, 2008).

Lastly to test the theory that RTAs foster exportation of countries with the best accessibility to external markets we introduce an indicator of network, denoted $\vartheta_{i t}$ in interaction with the dummy of $R T A_{i j t}$. The aim of this interaction is to determine whether the positive impact of RTA on trade is totally explained by hub countries in Africa.

Consequently trade costs in (2) can take different form according to our estimation:

$$
\phi_{o d t}=\left\{\begin{array}{c}
\psi_{1} R T A_{i j t}+b Z_{o d} \\
\psi_{1} R T A_{i j t}+\psi_{2} R T A_{j-o t}+\psi_{3} R T A_{i-d t}+f_{o d} \\
\psi_{4} F T A_{i j t}+\psi_{5} E I A_{i j}+f_{o d} \\
\psi_{1} R T A_{i j t}+\psi_{7} \vartheta_{i t} R T A_{i j t}
\end{array}\right.
$$

where $Z_{i j}$ is a set of bilateral variables (distance and dummies based on past colonial links, contiguity, etc), $\psi_{1}, \psi_{4}$ and $\psi_{5}$ are different measures of the trade creation of regional agreements while $\psi_{2}$ and $\psi_{3}$ (with negative signs) measure trade diversion.

The great advantage of individual-time fixed effect in (2) is to control for several variables such as change in internal infrastructures, internal conflicts and so on. However, the main drawback of importer/exporter-year effects is that trade diversion $\left(\psi_{2} R T A_{j-o t}, \psi_{3} R T A_{i-d t}\right)$ and network effects $\left(\psi_{7} \vartheta_{i t}\right)$ cannot be studied with that specification, fixed effects directly capture their variation over time at the destination or at the origin of exports. As a result our empirical strategy is in two parts. Section 3 estimates Equation (2) with importer/exporter-year effects and focus on trade creation to analyze:

1. Trade creation on the whole period (1955-2014) and over time by considering three sub-periods (1955-1970, 1970-1990, 1990-2014).

2. Trade creation by type of RTAs (Economic Integration Agreements, Free Trade Agreement and the provisions of the different RTAs)

Then, in Section 4, year-exporter and year-importer fixed effects are omitted in order to analyze trade diversion, the hub effect and the home market effect of RTAs. 


\subsection{Data and estimators}

While regional trade agreements have strongly boosted regional trade in Europe or in North America, intra-African trade remains very low despite several agreements, here we consider six of them: the Economic Community of West African States (ECOWAS) within which eight countries have a deeper integration with the West African Economic and Monetary Union (WAEMU). The Economic and Monetary Community of Central Africa (known as CEMAC from its name in French) which is the other monetary union of our sample. The Common Market for Eastern and Southern Africa (COMESA) which is the largest regional agreement in Africa with a free trade area and a customs union since 2009. We also analyze the Southern African Development Community (SADC) and lastly the East African Community (EAC). Appendix A provides a figure representing each country in the agreements signed. We compute a dummy taking one when these agreements enter in enforcement and zero otherwise.

We lead our analyzis of trade flows on the Bilateral Trade HIStorical series, TRADHIST, a database from the CEPII (see Fouquin and Hugot, 2016). This database is to our knowledge the sole to compil bilateral flows at the aggregate level with an historical perspective allowing to analyze the effects of RTA over the period 1955-2014. This period of time enables to consider a dummy of RTA that varies over time, with the entry (and sometimes the exit) of members. Furthermore, even on recent periods (e.g. the 90's), TRADHIST is more complete. Other databases coming exclusively from COMTRADE (e.g. BACI) have many missing data of trade between african countries before 1994 which is very problematic since many significant RTAs have been signed on that period. These databases however have the advantage to provide data at a more desaggregated level.

To analyze the nature of RTAs, i.e. traditional trade policies versus behind-theborder policies, we use data on trade agreement heterogeneity from Kohl, Brakman and Garretsen (2016). Analyzing the form and shape of agreements, they distinguish thirteen policy domains that are within the scope of the WTO's mandate, hereafter called the WTO+ provisions, four policy domains that are not, the WTOx provisions, and nine indicators of the agreements' institutional quality, IQ. The three indices are then combined to construct an overall measure of RTAs heterogeneity, denoted IC. Table (2.2) helps to understand how these data are built. The letter "C" indicates that the provision is covered by the agreement, "CE" means that the provision is covered and legally enforceable. For instance among the four WTOx provisions (capital mobility, 
competition, environmental issues, regulation of the labor market), two are included in ECOWAS, but only one is enforced, these informations are then used by Kolh et al. (2016) to build the different indicators (WTO+, WTOx, IC, IQ) between 1990 and 2014 .

Table 1: Provisions of RTAs

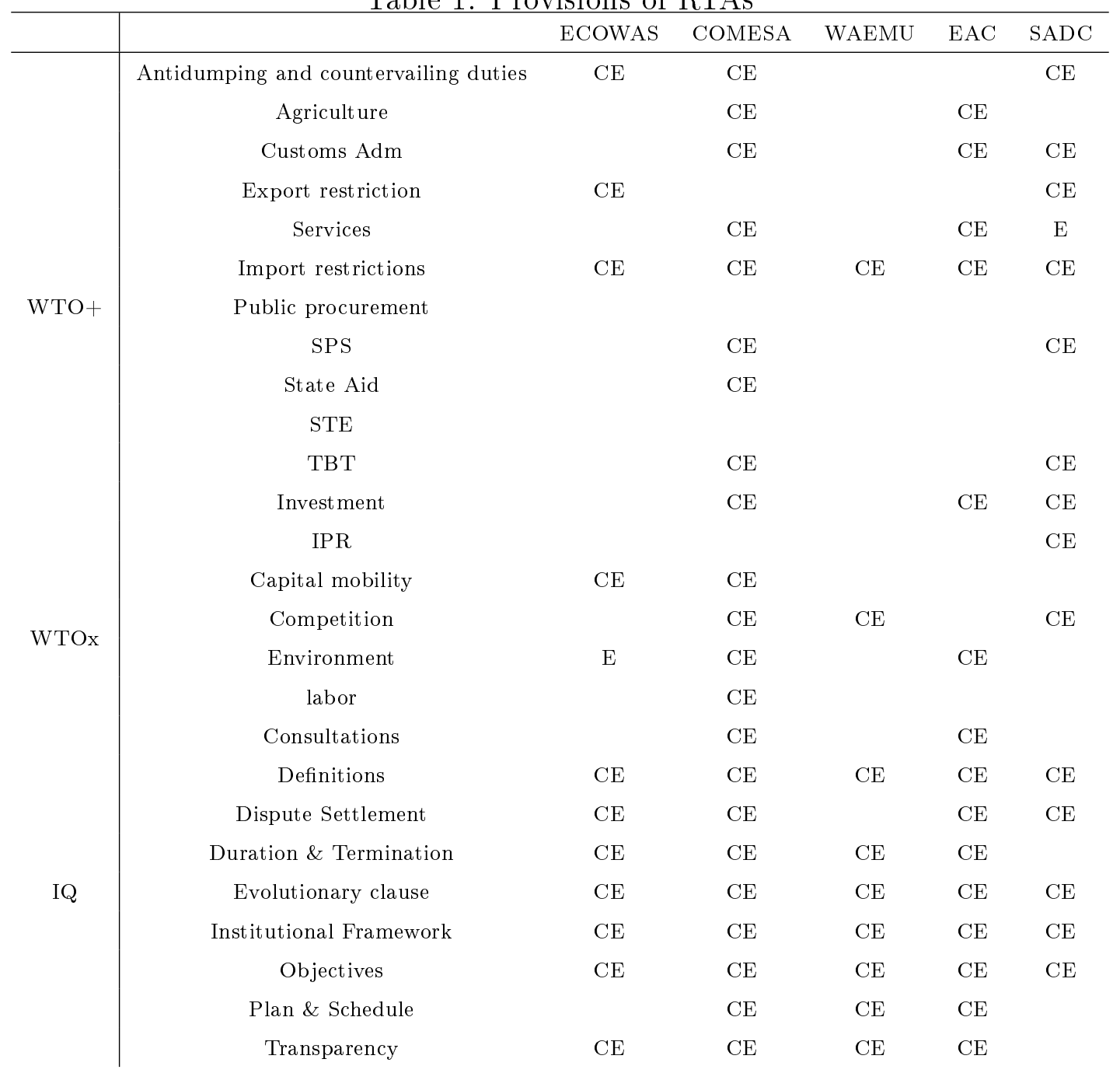

To control for bilateral relationship we used bilateral fixed effects or a vector of dummies coming from the database GEODIST of the CEPII, i.e. dummies variables taking one when countries are contiguous $\left(\right.$ contig $\left._{i j}\right)$, when one country was the colonizer of the other $\left(\operatorname{col}_{i j}\right)$, when the two countries were part of the same country (smctry $\left.y_{i j}\right)$, and when at least $9 \%$ of the population in both countries speak the same language $\left(\right.$ lang $\left._{i j}\right)$. 
To test the hub effect, we use two indicators. First, an indicator of network, the out degree centrality index which is computed with the following formula:

$$
\vartheta_{i t}^{\text {Network }}=\frac{\sum_{d \neq i}^{N} L_{i d}}{N-1}
$$

where $\sum_{j \neq i}^{N} L_{i j}$ is the total number of countries toward which country $i$ is exporting and $N$ the total number of countries.

Second, the market potential of Harris (1954), which measures the accessibility of distant market by weighting GDP by bilateral distance:

$$
\vartheta_{i t}^{\text {MarketAccess }}=\sum_{d \neq i}^{N} \frac{Y_{d}}{d_{i d}}
$$

Equation (2) is estimated with Poisson Pseudo-Maximum-Likelihood (PPML) which is the most appropriated estimator of the trade gravity equation. ${ }^{8}$

\section{Trade creation}

\subsection{On the impact of RTAs over time}

All the results reported in Table (2) shows that RTAs have significantly promoted trade. Column 1 depicts results of a standard gravity equation with individual fixed effects. The effect of RTAs in that specification is unrealistically high $\left(\psi_{1}=1.817\right)$, indicating that this traditional specification with individual fixed effects over-estimate trade creation. The same conclusion can be reach, when individual-time fixed effects are introduced, the coefficient still seems to be biased upward due to the lack of control.

\footnotetext{
${ }^{8}$ see Santos Silva and Tenreyro (2006) for detailed explanations and more recently Fally (2015, Proposition 1) which demonstrates that the estimated fixed effects with PPML are perfectly consistent with the multilateral resistances of the theoretical model
} 
Table 2: Trade Creation

\begin{tabular}{c|ccc}
\hline Period & \multicolumn{3}{|c}{$1955-2014$} \\
\hline $\operatorname{dep}=X_{\text {odt }}$ & $(1)$ & $(2)$ & $(3)$ \\
\hline$R T A_{\text {ijt }}$ & $1.817^{a}$ & $1.794^{a}$ & $1.087^{a}$ \\
& $(0.193)$ & $(0.060)$ & $(0.159)$ \\
$\log \left(d_{\text {od }}\right)$ & $-0.532^{a}$ & $-0.538^{a}$ & \\
& $(0.038)$ & $(0.009)$ & \\
$\log \left(G D P_{\text {ot }}\right)$ & $0.795^{a}$ & & \\
& $(0.061)$ & & \\
$\log \left(G D P_{d t}\right)$ & $0.726^{a}$ & & \\
& $(0.070)$ & & \\
contig $_{\text {od }}$ & $0.286^{b}$ & $0.299^{a}$ & \\
& $(0.135)$ & $(0.033)$ & \\
lang $_{\text {od }}$ & $0.319^{a}$ & $0.411^{a}$ & \\
& $(0.100)$ & $(0.042)$ & \\
comcol $_{\text {od }}$ & $0.494^{b}$ & $0.523^{a}$ & \\
& $(0.204)$ & $(0.059)$ & \\
smctry $_{\text {od }}$ & 0.353 & $0.351^{a}$ & \\
& $(0.253)$ & $(0.062)$ & \\
\hline Obs & 226553 & 241502 & 224785 \\
Pseudo $\mathrm{R}^{2}$ & 0.947 & 0.961 & 0.995 \\
$\log$ likelihood & -15016308 & -12318351 & -2517130.6 \\
\hline
\end{tabular}

Notes: $a b c$ denote significance at the 1,5 and 10 percent level respectively. Estimations have been done with the PPML estimator. Concerning fixed and variable effects: Column 1: $f_{o}, f_{d}, f_{t}$, Column 2: $f_{o t}, f_{d t}$ and Column $3 f_{o t}, f_{d t}, f_{o d}$.Regressions are performed on trade data of 69 countries (51 african countries, 17 non-african which are the african main importers and a rest of the world).

The average distance elasticity is closed to -0.5 which is smaller than the one reported by studies using log-linear estimation with the OLS estimator ${ }^{9}$ but in line with estimates using the PPML estimator. ${ }^{10}$ The GDP elasticities as well as contiguity, a common language and a common colonizer have the usual sign, size and significance.

The most demanding specification (Column 3), where both individual-time fixed effects and bilateral fixed effects are taken into account leads to a strong reduction of this coefficient, the effects of RTA is however still high (around 1) which contrasts with the conventional view that RTAs in Africa are almost useless.

The fact that the period analyzed is span on many decades (1955-2014) makes however hard the comparison with more recent RTAs implemented elsewhere in the world such as the NAFTA or the EU and also impede to analyze the heterogeneous

\footnotetext{
${ }^{9}$ According to the meta-analyzis of Disdier and Head (2008) the mean coefficient is -0.9 .

${ }^{10}$ Santos Silva and Tenreyro (2006) find an elasticity around -0.7 with PPML and an elasticity twice as large with OLS.
} 
impact of these agreement over time. In Table (3, Column 3) we thus analyze trade creation on different period, using all the possible controls, including the variable of preferential trade agreements $\left(P T A_{o d t}\right)$.

We find that RTAs in African have a smaller impact on trade than the NAFTA, or the EU, ${ }^{11}$ but are however strongly efficient, boosting trade by around $29 \%\left(e^{0.26}-1\right)$ on the most recent period. We can also observe an erosion of the effect of these RTAs with higher and realistic coefficient in 1970-1990 and an incredible huge coefficient for the period 1955-1970 which was however, also, an incredible period for African countries since it is the most representative era of struggles against colonialism to achieve independence. As detailled in Appendix, a vast number of RTAs have been signed on that period.

Table 3: Trade Creation

\begin{tabular}{c|ccc}
\hline Period & $1955-1970$ & $1970-1990$ & $1990-2014$ \\
\hline$R T A_{i j t}$ & $1.720^{a}$ & $0.372^{a}$ & $0.265^{b}$ \\
& $(0.438)$ & $(0.124)$ & $(0.133)$ \\
PT $A_{\text {odt }}$ & $0.271^{a}$ & $0.097^{a}$ & $0.269^{c}$ \\
& $(0.042)$ & $(0.035)$ & $(0.016)$ \\
\hline Obs & 167929 & 384992 & 719440 \\
Pseudo R & 0.989 & 0.992 & 0.991 \\
$\log$ likelihood & -128307.07 & -956602.13 & -4986422.6 \\
\hline
\end{tabular}

Notes: $a b c$ denote significance at the 1,5 and 10 percent level respectively. Estimations have been done with PPML. Robust clustered standard errors are reported under each coefficient. Individual and bilateral fixed effects $\left(f_{o t}, f_{d t}, f_{o d}\right)$ have been introduced in all regressions.

\subsection{On the heterogeneity of RTAs}

In order to take into account the fact that the dummy of $R T A_{i j t}$ encompasses agreement that are qualitatively different, trade creation is now analyzed by using Free Trade Agreements $\left(F T A_{i j t}\right)$ and Economic Integration Agreements $\left(E I A_{i j t}\right)$ dummies. Table (4, columns 1-2) shows that EIAs have a stronger impact on trade than FTAs. However the effect of EIAs on exports is decreasing over time as illustrated by the fall in the value of the coefficient (around 1.6 over the whole period and 0.43 during the most recent period) and by the rise of its standard error. This result is even more striking for FTAs: trade creation coming from FTAs is no longer significant between 1990 and 2014, indicating that most of gains of RTAs have been exhausted and that more ambitious

\footnotetext{
${ }^{11}$ Cipollina and Salvatici (2010) find in their meta-analyzis that the mean coefficient for NAFTA is equal to 0.90 while Head and Mayer (2014) find a coefficient equals to 0.36 for the EU.
} 
programs need to be put in place.

To go beyond the simple use of binary variables to capture the effect of RTAs, we introduce the various indices of trade agreement heterogeneity proposed by Kohl, Brakman and Garretsen (2016). The general variable of RTAs heterogeneity, IC, that combines the different kind of provisions, is not significant (Table (4, Column 3)). This is not surprising since African RTAs are not so heterogeneous, the number of provisions that goes beyond the WTO line, are for instance small and identical for the WAEMU, the EAC and the SADC (see the data description section). The result becomes more interesting by using the decomposition of this indice in order to understand which kind of provisions matters. Table (4, Column 3) indicates that only the $\mathrm{WTO}+$ provisions are trade promoting, while WTOx provisions are not significant. Contrarily to the finding of Kolh et al. (2016) that WTOx provisions reduce trade in general (i.e. in their sample of 296 Trade Agreements), it seems that the few behind-the-border conditions included in African RTAs have no effect on trade.

\begin{tabular}{|c|c|c|c|c|}
\hline dep $=X_{o d t}$ & $1955-2014$ & & $1990-2014$ & \\
\hline$F T A_{i j t}$ & $\begin{array}{c}0.886^{a} \\
(0.164)\end{array}$ & $\begin{array}{c}0.282 \\
(0.178)\end{array}$ & \multirow{7}{*}{$\begin{array}{c}0.518^{c} \\
(0.264) \\
-0.250 \\
(0.537)\end{array}$} & \\
\hline$E I A_{i j t}$ & $\begin{array}{c}1.674^{a} \\
(0.206)\end{array}$ & $\begin{array}{c}0.429^{c} \\
(0.248)\end{array}$ & & \\
\hline$R T A_{i j t}$ & & & & $\begin{array}{c}0.319 \\
(0.404)\end{array}$ \\
\hline RTAs heterogeneity (IC) & & & & \\
\hline In WTO (WTO+) & & & & $\begin{array}{c}0.833^{b} \\
(0.370)\end{array}$ \\
\hline Beyond WTO (WTOx) & & & & $\begin{array}{l}-0.370 \\
(0.294)\end{array}$ \\
\hline RTAs' institutional quality & & & & $\begin{array}{l}-0.275 \\
(0.604)\end{array}$ \\
\hline Obs & 224785 & \multicolumn{3}{|c|}{100102} \\
\hline Pseudo $\mathrm{R}^{2}$ & 0.995 & 0.997 & \multicolumn{2}{|c|}{0.996} \\
\hline log likelihood & -2511875.6 & -1473339.5 & -1473124.6 & -1472894.7 \\
\hline
\end{tabular}

Notes: ${ }^{a b c}$ denote significance at the 1, 5 and 10 percent level respectively. Estimations have been done with the PPML estimator. Robust clustered standard errors are reported under each coefficient. Individual and bilateral fixed effects $f_{o d}, f_{o t}$ and $f_{d t}$ have been introduced in all regressions. Regressions are performed between 69 countries among them 51 african countries, 17 separates one which are the african most importers during the recent period (1990-2014) and a rest of the world (ROW). The latter is an aggregate of 129 countries. 


\section{Testing theories}

The empirical strategy presented until now, based on fixed and time-varying effects, was the best strategy to identify trade creation, but represents a black box to measure the global effects of RTAs. In particular, the positive impact of trade creation needs to be relativized by considering trade diversion which is not possible with the empirical strategy adopted until now. Furthermore even if RTAs promote net trade creation on average, trade liberalization can have redistributive effect between countries in particular in sectors characterized by imperfect competition. Countries with bad accessibility to other markets and/or small countries, may loose activities in sectors with increasing returns due to RTAs, while the reverse occurs in countries with good market access.

\subsection{Trade diversion}

We now test the trade diversion hypothesis. Results are reported in Table (5), African agreements do not lead to export diversion according to these estimates. The same result is obtained concerning import diversion. Imports do not seem to significantly shift from a lower-cost to a higher cost source supply. A possible explanation can be that external partners are still the cheapest possible source of supply even after payment of tariffs, i.e. the price gap is so high that RTAs don't succeed to make African producers artificially competitive. Maybe varieties imported from the rest of the world are also enough different to not be crowding out by regional trade between African members. 
Table 5: Trade Diversion

\begin{tabular}{|c|c|c|}
\hline dep $=X_{o d t}$ & $1955-2014$ & 1990-2014 \\
\hline \multirow[t]{2}{*}{$R T A_{i j t}$} & $1.909^{a}$ & $2.040^{a}$ \\
\hline & $(0.208)$ & $(0.202)$ \\
\hline \multirow[t]{2}{*}{$R T A_{i-d t}$} & 0.084 & 0.098 \\
\hline & $(0.092)$ & $(0.077)$ \\
\hline \multirow[t]{2}{*}{$R T A_{j-o t}$} & 0.060 & $0.207^{b}$ \\
\hline & $(0.094)$ & $(0.092)$ \\
\hline \multirow{2}{*}{$\log \left(d_{o d}\right)$} & $-0.530^{a}$ & $-0.551^{a}$ \\
\hline & $(0.038)$ & $(0.038)$ \\
\hline \multirow[t]{2}{*}{$\log \left(G D P_{o t}\right)$} & $0.796^{a}$ & $0.706^{a}$ \\
\hline & $(0.062)$ & $(0.059)$ \\
\hline \multirow[t]{2}{*}{$\log \left(G D P_{d t}\right)$} & $0.726^{a}$ & $0.740^{a}$ \\
\hline & $(0.070)$ & $(0.060)$ \\
\hline \multirow[t]{2}{*}{ contig $_{\text {od }}$} & $0.295^{b}$ & $0.278^{b}$ \\
\hline & $(0.136)$ & $(0.138)$ \\
\hline \multirow{2}{*}{$\operatorname{lang}_{\text {od }}$} & $0.417^{b}$ & $0.456^{b}$ \\
\hline & $(0.196)$ & $(0.196)$ \\
\hline \multirow[t]{2}{*}{ comcol $_{\text {od }}$} & $0.498^{b}$ & $0.548^{c}$ \\
\hline & $(0.204)$ & $(0.119)$ \\
\hline \multirow[t]{2}{*}{ ethni_lang ${ }_{\text {od }}$} & -0.106 & -0.144 \\
\hline & $(0.188)$ & $(0.187)$ \\
\hline \multirow[t]{2}{*}{ smctry $_{o d}$} & 0.355 & 0.312 \\
\hline & $(0.253)$ & $(0.265)$ \\
\hline Obs & 226553 & 110388 \\
\hline Pseudo $\mathrm{R}^{2}$ & 0.947 & 0.950 \\
\hline log likelihood & -15014283 & -11976689 \\
\hline
\end{tabular}

Notes: ${ }^{a b c}$ denote significance at the 1, 5 and 10 percent level respectively. Estimations have been done with the PPML estimator. Robust clustered standard errors are reported under each coefficient. Individual and time fixed effects $f_{o}, f_{d}$ and $f_{t}$ have been introduced in all regressions. Regressions are performed between 69 countries among them 51 african countries, 17 separates one which are the african most importers during the recent period (1990-2014) and a rest of the world (ROW). The latter is an aggregate of 129 countries.

\subsection{Home market effect}

The most original result of the new trade theories is the Home Market Effect (hereafter HME), stating that trade integration will favor the country with the largest market. The interaction of increasing returns and imperfect competition gives birth to a more than proportional relationship between a country's share of regional production of a good and its share of regional demand.

To test the HME, we follow Hanson and Xiang (2005) who propose to select pairs of exporting countries that have a similar production technology and face common tariffs 
at destination. So taking the ratio of country o's exports to country $h$ 's exports toward the destination market $d$ for a particular good $s$ (using Equation, 1) gives:

$$
\frac{X_{o d, s}}{X_{h d, s}}=\frac{n_{o d, s}}{n_{h d, s}}\left(\frac{Y_{o, s}}{Y_{h, s}}\right)^{1-\sigma_{s}}\left(\frac{\tau_{o d}}{\tau_{h d}}\right)^{1-\sigma_{s}}
$$

Considering that trade costs take the following form $\tau_{o d, s}=d_{o d}^{\gamma_{s}}$ with $\gamma_{s}$ the elasticity of transportation costs with respect to distance. Now taking the exports of goods with high transport costs and strong scale economies, $s$, relative to the exports of goods with low transport costs and weak scale economies, denoted $r$, gives:

$$
\frac{X_{o d, s} / X_{h d, s}}{X_{o d, r} / X_{h d, r}}=\frac{n_{o d, s} / n_{h d, s}}{n_{o d, r} / n_{h d, r}} \frac{\left(Y_{o, s} / Y_{h, s}\right)^{1-\sigma_{s}}}{\left(Y_{o, r} / Y_{h, r}\right)^{1-\sigma_{r}}}\left(\frac{d_{o d}}{d_{h d}}\right)^{\left(1-\sigma_{s}\right) \gamma_{s}-\left(1-\sigma_{r}\right) \gamma_{r}}
$$

The sector $s$ is considered as the "treatment" industry and the sector $r$ as the "control" group. Finally the following 'difference-in-difference' specification of trade flows between countries is estimated by Hanson and Xiang (2004):

$$
\ln \frac{X_{o d, s} / X_{h d, s}}{X_{o d, r} / X_{h d, r}}=\alpha+\beta \ln \left(\frac{Y_{o, s}}{Y_{h, s}}\right)+\vartheta\left(Z_{o}-Z_{h}\right)+\delta \ln \left(\frac{d_{o d}}{d_{h d}}\right)+\varepsilon_{o h d, r s}
$$

The home-market effect is observed whether $\beta>0$ i.e. whether larger countries export relatively more of high-markup, high-transport cost goods. To identify the HME, it is necessary to consider pairs of exporting countries that face common trade policy barriers and similar production costs (in order to minimize the risk to mislead the HME with comparative advantage). Thus origin countries, $\{o, h\}$, are now exclusively african countries, $\{i, j\}$. We extend the methodology of Hanson and Xiang (2004) by considering the following 'difference-in-difference' specification by using a panel version of (6) and by introducing our dummy of RTA as follows:

$\ln \frac{X_{i d t, s} / X_{j d t, s}}{X_{i d t, r} / X_{j d t, r}}=\alpha+\beta R T A_{i j t} \ln \left(\frac{Y_{i t, s}}{Y_{j t, s}}\right)+R T A_{i j t}+\ln \left(\frac{Y_{i t, s}}{Y_{j t, s}}\right)+\vartheta\left(Z_{i}-Z_{j}\right)+f_{t}+\delta \ln \left(\frac{d_{i d}}{d_{j d}}\right)+\varepsilon_{i j d, r s}$

In comparison with Hanson and Xiang (2004), time fixed effects are introduced and our test of the HME is more demanding: the HME due to RTAs between $i$ and $j$ is here analyzed on third market $d$.

Equation (7) is estimated to test the HME for African countries. In Table (4.2) we only report the estimation of interaction term between RTAs and GDPs $\left(R T A_{i j t}\left(Y_{i t, s} / Y_{j t, s}\right)\right)$, 
allowing to discriminate whether RTAs are beneficial to countries with the highest demand in particular for industries with high transport costs and differentiated products. Each column reports results for an industry of this type, while in rows we consider different type of control groups (i.e. sector with low trade costs and low differenciation). The different industries are categorized according to the classification of Hanson and Xiang (2005) reported in Appendix C. For instance "Paper and paperboard" belongs to industries considered as operating under increasing returns, with transport costs in the 65th percentiles (and an elasticity $\sigma=4.3$ ), while "Paper machinery" is at the bottom of the distribution i.e. between the 5 th and 10 th percentiles (and an elasticity $\sigma=8.5$ ).

There are some evidence of the HME, but in the majority of cases, this effect is not significant or ambiguous. For instance for "paper and paperboard" the coefficient is significantly negative when taking as a reference "nonferrous metals", positive when considering "construction machinery" and not significant when considering "refrigeration machinery". For "iron and steel", results are less ambiguous, but the positive sign of the HME's coefficient is significant only with three particular references (nonferous metals, medical instruments and construction machinery). The same comments can be done for products like "steel wire", "glassware and glass" or "clay". 
Table 6: RTA and HME

\begin{tabular}{|c|c|c|c|c|c|c|c|c|}
\hline & $\begin{array}{l}\text { Paper and } \\
\text { paperboard }\end{array}$ & $\begin{array}{c}\text { Iron and } \\
\text { steel }\end{array}$ & Steel wire & $\begin{array}{c}\text { Inorganic } \\
\text { chem. }\end{array}$ & $\begin{array}{l}\text { Glassware } \\
\text { and glass }\end{array}$ & Steel pipes & $\begin{array}{c}\text { Furnace and } \\
\text { steel mill }\end{array}$ & Clay \\
\hline \multirow[t]{2}{*}{ S.nonferrous metals } & $-0.887^{a}$ & $1.162^{b}$ & $0.354^{b}$ & & $0.444^{c}$ & 0.180 & & \\
\hline & $(0.105)$ & $(0.474)$ & $(0.168)$ & & $(0.239)$ & $(0.196)$ & & \\
\hline \multirow[t]{2}{*}{ Medical instruments } & $0.213^{c}$ & $0.793^{b}$ & $0.366^{c}$ & $0.250^{c}$ & $-0.228^{c}$ & 0.013 & 0.497 & 0.234 \\
\hline & $(0.122)$ & $(0.310)$ & $(0.204)$ & $(0.148)$ & $(0.138)$ & $(0.121)$ & $(0.326)$ & $(0.195)$ \\
\hline \multirow[t]{2}{*}{ Paper machinery } & 0.029 & 0.083 & 0.371 & $-0.961^{a}$ & $1.584^{a}$ & -0.201 & 0.166 & $0.945^{c}$ \\
\hline & $(0.307)$ & $(0.243)$ & $(0.448)$ & $(0.370)$ & $(0.559)$ & $(0.201)$ & $(0.176)$ & $(0.499)$ \\
\hline \multirow[t]{2}{*}{ Fur goods } & $0.271^{c}$ & 0.302 & 0.132 & & 0.135 & $0.879^{a}$ & $1.539^{b}$ & $0.323^{a}$ \\
\hline & $(0.157)$ & $(0.533)$ & $(0.127)$ & & $(0.093)$ & $(0.198)$ & $(0.679)$ & $(0.115)$ \\
\hline \multirow[t]{2}{*}{ Metal w machinery } & $1.417^{c}$ & 0.116 & 0.540 & 0.481 & $0.614^{a}$ & 0.324 & 1.223 & $3.004^{b}$ \\
\hline & $(0.800)$ & $(0.167)$ & $(0.337)$ & $(0.325)$ & $(0.200)$ & $(0.202)$ & $(0.719)$ & $(1.252)$ \\
\hline \multirow[t]{2}{*}{ Trailers and campers } & 0.038 & 0.080 & 0.074 & $-0.508^{b}$ & 0.194 & -0.126 & -0.270 & $0.991^{a}$ \\
\hline & $(0.181)$ & $(0.284)$ & $(0.135)$ & $(0.198)$ & $(0.209)$ & $(0.080)$ & $(0.236)$ & $(0.370)$ \\
\hline \multirow[t]{2}{*}{ Textile machinery } & -0.429 & 0.165 & -0.699 & 0.254 & -0.006 & $-0.503^{a}$ & 0.145 & -0.178 \\
\hline & $(0.281)$ & $(0.460)$ & $(0.427)$ & $(0.308)$ & $(0.190)$ & $(0.175)$ & $(0.178)$ & $(0.251)$ \\
\hline \multirow[t]{2}{*}{ Refrigeration machinery } & 0.331 & 0.195 & $0.587^{a}$ & $-0.171^{c}$ & $0.303^{b}$ & 0.120 & $0.667^{b}$ & $0.350^{c}$ \\
\hline & $(0.315)$ & $(0.316)$ & $(0.201)$ & $(0.100)$ & $(0.151)$ & $(0.445)$ & $(0.277)$ & $(0.210)$ \\
\hline \multirow[t]{2}{*}{ Musical instruments } & 0.111 & 0.186 & -0.035 & $-0.497^{a}$ & $0.170^{c}$ & $-0.173^{b}$ & $0.294^{b}$ & $0.352^{a}$ \\
\hline & $(0.134)$ & $(0.208)$ & $(0.176)$ & $(0.086)$ & $(0.094)$ & $(0.069)$ & $(0.133)$ & $(0.120)$ \\
\hline \multirow[t]{2}{*}{ Construction machinery } & $0.492^{b}$ & $0.633^{a}$ & $0.545^{b}$ & $0.427^{a}$ & 0.225 & & $0.700^{a}$ & $1.093^{a}$ \\
\hline & $(0.221)$ & $(0.214)$ & $(0.238)$ & $(0.137)$ & $(0.262)$ & & $(0.208)$ & $(0.231)$ \\
\hline \multirow[t]{2}{*}{ Farm machinery } & 0.311 & 0.232 & 0.031 & 0.273 & $0.876^{a}$ & 0.266 & 0.571 & $0.564^{c}$ \\
\hline & $(0.285)$ & $(0.265)$ & $(0.253)$ & $(0.233)$ & $(0.322)$ & $(0.423)$ & $(0.562)$ & $(0.335)$ \\
\hline \multirow[t]{2}{*}{ Pens pencils } & & 0.794 & 0.031 & $1.208^{b}$ & 0.402 & -0.170 & -0.056 & $2.510^{a}$ \\
\hline & & $(0.591)$ & $(0.380)$ & $(0.488)$ & $(0.321)$ & $(0.127)$ & $(0.160)$ & $(0.939)$ \\
\hline \multicolumn{9}{|c|}{$\begin{array}{l}\text { Notes: This table shows estimated coefficient of interaction between RTA and log relative GDP on relative industry exports. Superscript } \\
a b c \text { denote significance at the } 1,5 \text { and } 10 \text { percent level respectively. Estimations have been done with PPML and time fixed effects have } \\
\text { been introduced in all column. Clustered standard errors are reported under each coefficient. Our data contain } 48 \text { African countries as } \\
\text { exporters and } 69 \text { importing countries which include this } 48 \text { african and } 21 \text { other, mainly euro zone countries. To whom we add USA, Great } \\
\text { Britain and Sweden. We introduce a set of continuous and dummy variables wich are log and level differenced. Namely relative distance, } \\
\text { sharing common language, common borders, haved common colonizer and sharing the same historical land. In order to control comparative } \\
\text { advantages effect, estimations are done with the log difference of the share of mineral export in the total trade. }\end{array}$} \\
\hline
\end{tabular}

\subsection{Hub effects}

The economic size cannot totally erase the economical geography: another element that can play with or against the home market effect is the "hub effect" (Krugman, 1993; Behrens et al. 2006). With trade liberalization, countries with the best access to the rest of the world become platforms of exports, attracting and creating activities which can lead to desindustrialization in partners countries (Puga and Venables, 1997; Ossa, 2011; Mossay and Tabuchi, 2015). This result, which may be considered as a folktheorem of models à la Krugman (1980), has never been tested or analyzed in details 
in empirical studies concerning african countries.

Columns 1-2 of Table (7) reveal that once the positive impact of RTAs on trade of African hubs countries is taken into account $\left(R T A_{i j t} \times \vartheta_{i t}\right)$, RTAs are no longer significant. This result supports the theoretical result that RTAs are mainly beneficial to countries with a good accessibility to other markets (core countries versus the periphery). In Column 3-4 the same regression is done but using the market access as a variable of hub effects. The same result is obtained over the whole period, but during the most recent period, countries with the best market access have not beneficiated of RTAs, i.e. the interaction is no longer significant. This last result might explained where the declining effect of RTAs has occured. 
Table 7: Creation Trade

\begin{tabular}{|c|c|c|c|c|}
\hline & \multicolumn{2}{|c|}{$\vartheta_{i t}^{N e t w o r k}$} & \multicolumn{2}{|c|}{$\vartheta_{i t}^{\text {MarketAccess }}$} \\
\hline $\operatorname{dep}=X_{o d t}$ & $1955-2014$ & $1990-2014$ & $1955-2014$ & 1990-2014 \\
\hline \multirow{2}{*}{$R T A_{i j t}$} & -1.076 & -1.013 & -5.002 & -8.334 \\
\hline & $(0.655)$ & $(0.664)$ & $(3.424)$ & $(6.400)$ \\
\hline \multirow{2}{*}{$R T A_{i j t} \times \vartheta_{i t}$} & $4.459^{a}$ & $4.414^{a}$ & 0.339 & 0.029 \\
\hline & $(0.985)$ & $(1.002)$ & $(0.239)$ & $(0.341)$ \\
\hline \multirow[t]{2}{*}{$\vartheta_{i t}$} & 0.433 & $0.592^{c}$ & $0.368^{b}$ & 0.547 \\
\hline & $(0.416)$ & $(0.338)$ & $(0.186)$ & $(0.345)$ \\
\hline \multirow[t]{2}{*}{$\log \left(d_{o d}\right)$} & $-0.530^{a}$ & $-0.550^{a}$ & $-0.528^{a}$ & $-0.548^{a}$ \\
\hline & $(0.038)$ & $(0.038)$ & $(0.038)$ & $(0.038)$ \\
\hline \multirow[t]{2}{*}{$\log \left(G D P_{o t}\right)$} & $0.669^{a}$ & $0.699^{a}$ & $0.827^{a}$ & $0.705^{a}$ \\
\hline & $(0.052)$ & $(0.060)$ & $(0.069)$ & $(0.066)$ \\
\hline \multirow[t]{2}{*}{$\log \left(G D P_{d t}\right)$} & $0.615^{a}$ & $0.740^{a}$ & $0.720^{a}$ & $0.737^{a}$ \\
\hline & $(0.060)$ & $(0.060)$ & $(0.069)$ & $(0.059)$ \\
\hline \multirow[t]{2}{*}{ contig $_{o d}$} & $0.301^{b}$ & $0.279^{b}$ & $0.325^{b}$ & $0.311^{b}$ \\
\hline & $(0.135)$ & $(0.138)$ & $(0.138)$ & $(0.140)$ \\
\hline \multirow{2}{*}{$\operatorname{lang}_{\text {od }}$} & $0.410^{b}$ & $0.452^{b}$ & $0.390^{c}$ & $0.428^{c}$ \\
\hline & $(0.195)$ & $(0.195)$ & $(0.218)$ & $(0.222)$ \\
\hline \multirow[t]{2}{*}{ comcol $_{o d}$} & $0.557^{a}$ & $0.583^{b}$ & $0.539^{a}$ & $0.586^{a}$ \\
\hline & $(0.208)$ & $(0.227)$ & $(0.204)$ & $(0.223)$ \\
\hline \multirow[t]{2}{*}{ ethni_lang od } & -0.106 & -0.142 & -0.140 & -0.184 \\
\hline & $(0.188)$ & $(0.187)$ & $(0.216)$ & $(0.220)$ \\
\hline \multirow{2}{*}{ smctry $y_{o d}$} & 0.361 & 0.314 & 0.376 & 0.337 \\
\hline & $(0.251)$ & $(0.265)$ & $(0.252)$ & $(0.263)$ \\
\hline Obs & 226553 & 110388 & 226553 & 114681 \\
\hline Pseudo $\mathrm{R}^{2}$ & 0.948 & 0.950 & .94530016 & 0.948 \\
\hline log likelihood & -11982237 & -11905886 & -15064799.2 & -12256704 \\
\hline
\end{tabular}

Notes: $a b c$ denote significance at the 1,5 and 10 percent level respectively. Estimations have been done with the PPML estimator. Robust clustered standard errors are reported under each coefficient. Individual and time fixed effects $f_{o}, f_{d}$ and $f_{t}$ have been introduced in all regressions. Regressions are performed between 69 countries among them 51 African countries, 17 separates one which are the african most importers during the recent period (1990-2014) and a rest of the world (ROW). The latter is an aggregate of 129 countries.

\section{Counterfactual scenarios}

\subsection{RTAs Gains}

To analyze the impact of RTAs at the country level, we resort to the methodology proposed by Magee (2008).

First, in order to get a prediction of trade flows in the absence of RTA, we operate a withdrawal of each agreement in our database by setting $R T A_{i j t}=0$ and we estimate 
our gravity equation with individual-time fixed effects; the predicted value obtained is denoted $\widehat{X}_{i j t}$. Second, we compute the country $j$ 's total imports from other countries within the regional trade agreement $k$, defined by $X_{j t}^{k}=\sum_{i \in R T A^{k}} X_{i j t}^{k}$, and the predicted imports from the same partners without the RTA enforcement, $\widehat{X}_{j t}^{k}=\sum_{i \in R T A^{k}} \widehat{X}_{i j t}^{k}$. Since trade creation is defined by the fact that after the enforcement of an agreement, members start to trade goods which were not traded before, we need to measure trade expansion, hereafter denoted $T E_{j t}$, that are defined by the difference between the actual exports and the predicted counterfactual exports without this regional trade agreement:

$$
T E_{j t}=\left\{\begin{array}{c}
X_{j t}^{k}-\widehat{X}_{j t}^{k} \text { if } X_{j t}^{k} \geq \widehat{X}_{j t}^{k} \\
0 \quad \text { if } X_{j t}^{k}<\widehat{X}_{j t}^{k}
\end{array}\right.
$$

Turning to trade diversion, we have to consider goods which were traded with nonmembers before the enforcement of the RTA and that are traded between members after it. In other words, trade diversion occurs when trade expansion is followed by a decreasing extra-bloc trade. By denoting $X_{j t}^{\notin k}=\sum_{i \notin R T A^{k}} X_{i j t}^{\notin k}$ the total import of country $j$ from countries outside the regional agreement $k$, and $\widehat{X}_{j t}^{\notin k}=\sum_{i \notin R T A^{k}} \widehat{X}_{i j t}^{\notin k}$ the predicted value from the same partners but without the RTA enforcement, we can measured the following trade diversion, hereafter denoted $T D_{j t}$ :

$$
T D_{j t}=\left\{\begin{array}{c}
T E_{j t} \text { if } \widehat{X}_{j t}^{\notin k}-X_{j t}^{\notin k} \geq T E_{j t} \\
\widehat{X}_{j t}^{\notin k}-X_{j t}^{\notin k} \text { if } T E_{j t}>\widehat{X}_{j t}^{\notin k}-X_{j t}^{\notin k}>0 \\
0 \text { if } \widehat{X}_{j t}^{\notin k}-X_{j t}^{\notin k} \leq 0
\end{array}\right.
$$

With these variables in hand, we measure trade creation as the trade expansion not reduced by trade diversion:

$$
T C_{j t}=T E_{j t}-T D_{j t}
$$

To get insight into how gains are linked to some characteristics of members, we present these trade creation with respect to the variable of network presented previously. 
Figure 1: Relation between RTA associated trade creation and individual country centrality

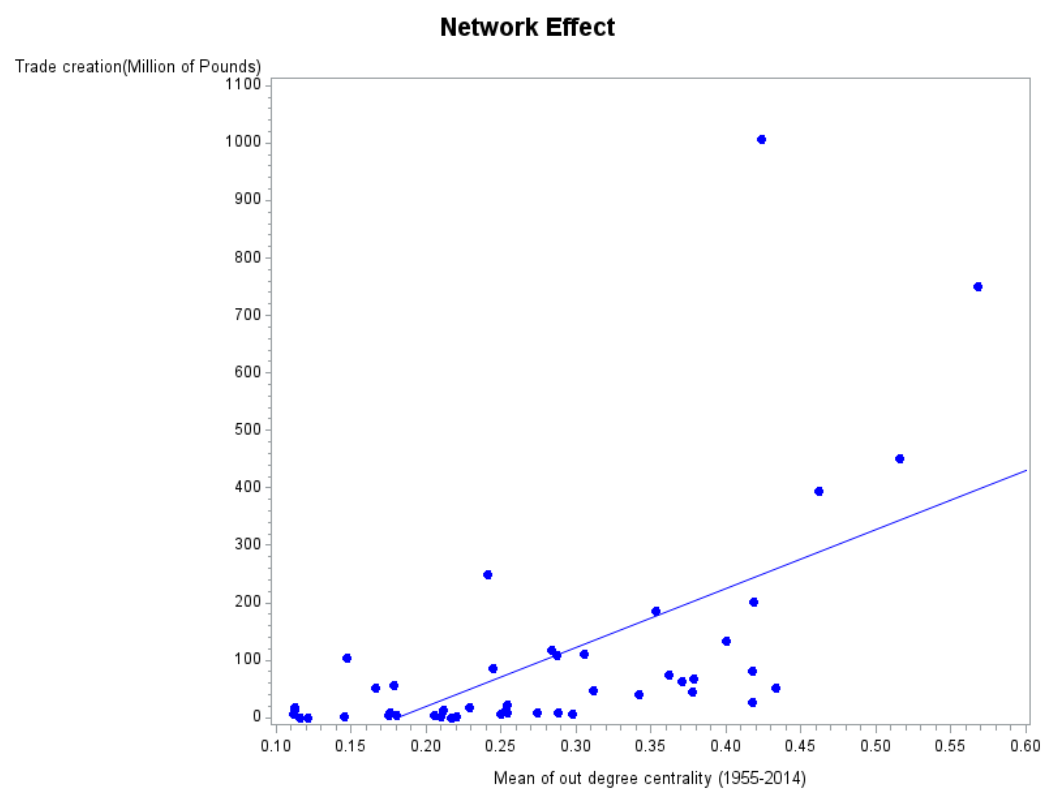

This scatter plot illustrates the hub hypothesis identified in the previous estimations, countries with the best network have more trade creation than other members. The positive relationship is particularly strong above 100 millions, showing that countries that are the most integrated are indeed those that disproportionnaly gain from RTAs.

We report in Appendix D, the detail of these results by presenting trade creation by individuals. Considering countries that belong to ECOWAS or CEMAC, one can observe that relative large countries (e.g. Nigeria) win more (in percentage of their trade) than small ones (Liberia). Gains are however much more substantial in more integrated areas (e.g. WAEMU or SACU) and in these groups small countries seem to benefit of aggreements in a similar way than large countries. For instance considering WAEMU, trade creation (in relative term) is equivalent for Togo and Senegal, or for Benin and Cote d'Ivoire. RTAs in Africa have also been beneficial to small countries, the amounts gained in absolute term remain however small.

\subsection{Back to Autarky}

Since our estimations reject the model of monopolistic competition (Section 4), we use the perfect competition model of Costinot et al (2012) and Mayer et al. (2018) to compute trade and welfare losses due to a return to autarky for African countries. This represents an alternative scenario concerning the possibility that in absence of RTAs, 
countries can return to their default position with high tariffs and other restrictive trade barriers. In other terms, even if there is no large creation effect in general (Section 3), the usefulness of RTAs has to be considered in light of the worst scenario: autarky.

Let's first improve the presentation of the model that leads to the gravity equation (1) presented in Section 1. Introducing labor as the sole factor of production in this Equation (1) with $w_{o}=Y_{o} / L_{o}$ yields :

$$
X_{o d}=\pi_{o d} X_{o}=\frac{w_{o}^{\sigma} P_{o}^{1-\sigma} \dot{\phi}_{o d}}{\sum_{l}\left(w_{l}^{\sigma} P_{l}^{1-\sigma} \dot{\phi}_{o l}\right)} X_{o}
$$

The change of trade share (denoted $\dot{\pi}_{o d}$ ) after a shock can be expressed as a function of predicted output $(\dot{Y})$, of country trade share $\left(\pi_{o l}\right)$ excluding $d$, of trade costs change $\left(\dot{\phi_{\text {od }}}\right)$ and of the CES price index $(\dot{P}):^{12}$

$$
\dot{\pi}_{o d}=\frac{\pi_{o d}^{\prime}}{\pi_{o d}}=\frac{\dot{\phi}_{o d} \dot{P}_{o}^{1-\sigma} \dot{Y}_{o}^{1-\sigma}}{\sum_{l} \pi_{l d} \dot{P}_{l}^{1-\sigma} \dot{\phi}_{l d} \dot{Y}_{l}^{1-\sigma}} .
$$

Introducing this trade share in the market clearing condition $\dot{Y}_{o}=\frac{1}{Y_{o}} \sum_{d} \pi_{o d}^{\prime} X_{d}^{\prime}$ gives:

$$
\dot{Y}_{o}=\frac{1}{Y_{o}} \sum_{d=1}^{n} \frac{\pi_{o d} \dot{\phi}_{o d} \dot{Y}_{o}^{1-\sigma}}{\sum_{l} \pi_{l d} \dot{\phi}_{l d} \dot{Y}_{l}^{1-\sigma}} \dot{Y}_{d} X_{d}
$$

Then, to solve the model we have to compute and to use the predicting time varying trade costs given by $\hat{\phi_{\text {odt }}}=\psi_{1} R T A_{i j t}+b P T A_{\text {odt }}$ with coefficients coming from our estimations (Table 3, Column 3).

This statistic is used to generate the new values of $\dot{p}_{d}=\sum_{l}\left(w_{l}^{\sigma} \dot{P}_{l}^{1-\sigma} \dot{\phi}_{o l}\right)$. These new variables help to compute $X_{o d}$. The iteration of the new matrix obtained allows to find the equilibrium $\dot{Y}_{o}$ for which $\dot{\pi}_{o d}=0$. Finally to simulate the model, we need internal trade flows for all countries then we turn to the EORA database which gives input-output tables including these flows. We choose the 2006's table to run our counterfactual.

Table 8 shows results from this simulation expressed as a percentage change. Columns 2 describes the indirect effect of the shock i.e. measuring the effect of autarky on multilateral resistances leaving incomes unchanged. Trade is predicted remaining output

\footnotetext{
${ }^{12}$ We undertake here a very brief presentation of the model, the reader interested by the details will find a complete presentation in Costinot et al (2012) and Mayer et al. (2018).
} 
and wage constants. In contrast, in the General Equilibrium Trade Impact (GETI) presented in Column 3, wages and GDPs is also adjusted to trade cost changes.

Then Column 3 represents the welfare's change aproximated by real income (wage on price index) associated with our scenario computed as $\dot{\pi}_{d d}^{1 /(1-\sigma)}$.

In comparison with the previous results (Table 4,7), this new analysis shows that RTAs have a substantial positive effect on trade during the most recent period (19902014).

The back to autarky shows that African RTAs lead to a positive impact on exports even if it is small-scale magnitude : only 3.7\% increase for African countries. These results are however heterogeneous with strong impact on exports of some countries (e.g. a $10 \%$ increases in Somalia). Concerning real GDP, the impact of RTAs is relatively small, on average African countries have a welfare gain around 0.44\%. Only Benin and Tanzania record an important welfare gain. This relative small impact of RTAs on welfare is quite logical since trade flows are small and represent a small share of GDPs in Africa. These results are also in accordance with the literature, calculating the "cost of Non-Europe", Mayer et al (2018) find a welfare gain around $4.4 \%$ for European countries. Because the initial African flows were smaller than the European initial trade, it is not surprising that even significant change in exports provides a tiny changes in the share of expenditure that is spent locally in Africa and as a result involves a small gains in term of real GDPs. 
Table 8: General Equilibrium Effects from Autarky

Country Indirect GETI Welfare

Effect

\begin{tabular}{cccc}
\hline Angola & 2.795 & 3.582 & 0.060 \\
Burundi & 2.507 & 5.042 & 0.092 \\
Benin & 2.094 & 4.457 & 10.112 \\
Burkina Faso & 2.092 & 7.41993 & 0.175 \\
Botswana & 2.487 & 2.944 & 0.120 \\
Chad & 0.666 & 2.060 & 0.066 \\
CAF & 0.664 & 3.676 & 0.047 \\
Côte d'ivoire & 2.120 & 2.149 & 0.165 \\
Cameroon & 0.674 & -0.199 & 0.018 \\
COG & 0.668 & 0.652 & 0.010 \\
Capo verde & 2.070 & 2.027 & 0.005 \\
Djibouti & 2.519 & 1.106 & 0.054 \\
Egypt & 3.160 & 3.295 & 0.056 \\
Ethiopie & 2.385 & 3.392 & 0.036 \\
Gabon & 0.670 & 0.867 & 0.039 \\
Ghana & 2.150 & 5.891 & 0.020 \\
Guinea & 2.171 & 4.284 & 0.002 \\
Gambia & 2.037 & 8.021 & 0.062 \\
Kenya & 2.775 & 1.713 & 0.059 \\
Liberia & 2.093 & 3.845 & 0.004 \\
Libya & 2.411 & 2.713 & 0.283 \\
Lesotho & 1.310 & 1.968 & 0.028
\end{tabular}

Notes : The benchmark year is 2006. Indirect and GETI are the country's mean facing all others countries. Results are in percentage. 
Table 9: General Equilibrium Effects from Autarky (continued)

\begin{tabular}{cccc} 
Country & $\begin{array}{c}\text { Indirect } \\
\text { Effect }\end{array}$ & GETI & Welfare \\
\hline MAR & 0.423 & 0.223 & 0.046 \\
Madagscar & 2.997 & 5.244 & 0.150 \\
Mali & 2.092 & 9.747 & 0.162 \\
Mozambique & 1.125 & 7.289 & 0.411 \\
Mauritania & 0.015 & -0.316 & 0.003 \\
Mauritius & 3.268 & 4.829 & 0.002 \\
Malawi & 2.976 & 8.318 & 0.010 \\
Niger & 2.194 & 5.188 & 0.004 \\
Nigeria & 2.059 & 1.424 & 0.288 \\
Rwanda & 2.508 & 8.067 & 0.056 \\
Senegal & 2.096 & 1.342 & 0.170 \\
Sierra leone & 2.039 & 4.281 & 0.049 \\
Somalia & 2.174 & 10.279 & 0.243 \\
South Africa & 1.489 & 0.517 & 0.471 \\
Swaziland & 3.134 & 0.125 & 0.0004 \\
Seychelle & 1.486 & 0.494 & 0.008 \\
Tanzania & 1.589 & 4.495 & 4.000 \\
Togo & 2.108 & 0.887 & 0.251 \\
Tunisia & 0.581 & -0.238 & 0.239 \\
Uganda & 2.505 & 6.172 & 0.005 \\
Zambia & 2.812 & 7.001 & 0.520 \\
Zimbabwe & 3.003 & 9.272 & 0.471 \\
Mean & 1.982 & 3.762 & 0.443
\end{tabular}

Notes : The benchmark year is 2006. Indirect and GETI are the country's mean facing all others countries. Results are in percentage.

\section{Concluding remarks}

The marginalization of Africa in the world trade system is still a reality. ${ }^{13}$ Africa's share of world exports has declined from about 6 percent in 1974 to 1.6 percent in 1995, and even if this number has since more than doubled it only reached 3.2 percent in $2014 .{ }^{14}$ The poor success of African exporters on the world market is all the more disappointing given that many preferential agreements have been implemented to foster

\footnotetext{
${ }^{13}$ Sachs and Warner (1997) and Subramanian and Tamirisa (2001) consider the marginalization of Africa as a consequence of a lack of trade integration while Foroutan and Pritchett (1993) and Rodrik (1998) view this marginalization as a consequence of their low income levels.

${ }^{14}$ Authors' calculation from Comtrade.
} 
African exports (see Candau and Jean, 2009). In this respect, RTAs seem a natural way for African countries to start their integration and then to win influence on international markets. Regional Trade Agreements are one of the rare political tool available to foster economic relationships between different countries but their effectiveness in promoting trade has been questioned.

By using a wide period of analyzis, we find that RTAs were trade promoting over the period 1955-1990 but less successful more recently. To explain this result, the aim of this study has been to take into account the heterogeneity of the RTAs and of the countries involved. A "home market effect", beneficial to large countries but detrimental to small ones, has not been detected; but countries that are well connected to international markets were clearly the winners in RTAs in the first era of integration (1955-1990).

It may be interesting in the future to pursue this analyzis in order to quantify the cause of the gains erosion found here. The proliferation of RTAs between African countries and the numerous preferential trade agreements signed with developed countries have certainly contribuated to make RTAs less meaningful, but to what extent? Based on current estimates it is also possible to use simple models of international trade to quantify whether more ambitious RTAs can be more efficient than the current ones ${ }^{15}$

\section{Appendix A}

The following Chart shows the RTAs notified to the WTO and analyzed in this paper, it also illustrates to what extent these agreements are inter-linked.

\footnotetext{
${ }^{15}$ For instance to assess the impact of the recent Tripartite Free Trade Area agreement which has a large geographical coverage, including 26 African countries.
} 

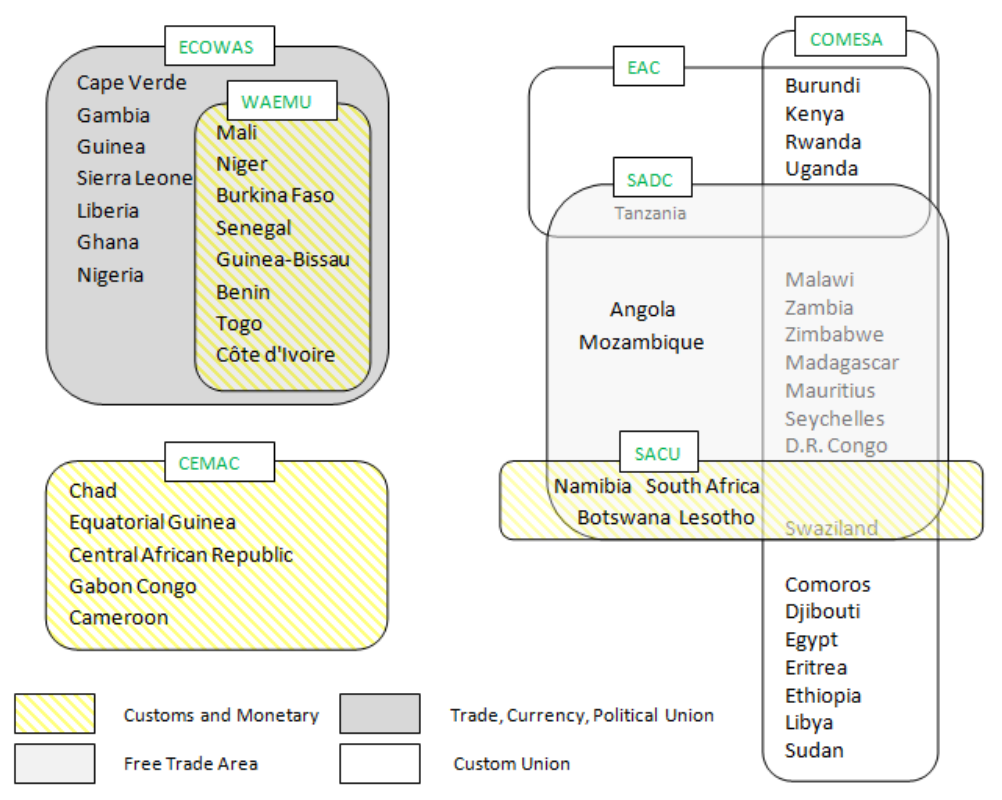

Figure 2: Spaghetti bowl of RTAs in Africa

The origin of this Spaghetti bowl, comes from the 1950s. During that period, French and English speaking countries come together to form the first Regional Trade Agreement in Sub-Saharan Africa.

Successive Regional Trade Agreements were created, namely West African Customs Union (WACU) and Customs Union of West African States (CUWAS) for West Africa. Equatorial Customs Union (ECU) and Central African Customs and Economic Union (CACEU) for Central Africa and the last one is East African Community (EAC) for the east of the continent. Central and West African agreements are better known by their French acronyms which are respectively: UDAO, UDEAO for West Africa and UDE, UDEAC for Central Africa.

Regional agreements in West Africa start in 1959 with seven members engaged in UDAO with his headquarters in Abidjan. These members were Benin, Burkina Faso, Côte d'Ivoire, Mali, Niger, Senegal and Mauritania. UDAO encounters many difficulties among which the distribution of customs revenues collected on imports. It was replaced by UDEAO conserving the same membership.

Concerning RTAs in Central Africa, Central African Republic, Gabon, Chad and Congo are the founding members of UDE which was established in june 1959 and joined by Cameroun in 1962. This union moves on to UDEAC in 1964 with the same members exepted Chad. 
The only English-speaking agreement on that period was the East African Community. Since 1917, EAC was a political union before to become an economic community in june 1967. The treaty was signed between Kenya, Tanzania and Uganda but was quickly dissolved in 1977 in reason of internal opposition and war in Uganda.

\section{Appendix B}

Table 10: Main right hand side variables correlation table

\begin{tabular}{|c|c|c|c|c|c|c|c|c|c|}
\hline & $R T A_{i j t}$ & dist $_{\text {od }}$ & $\mathrm{comcol}_{\text {od }}$ & smctry $y_{\text {od }}$ & contig $_{\text {od }}$ & $\operatorname{lang}_{\text {od }}$ & ethni_lang od & $G D P_{o t}$ & $G D P_{d t}$ \\
\hline$R T A_{i j t}$ & 1.0000 & & & & & & & & \\
\hline$d_{i s t}{ }_{o d}$ & -0.3734 & 1.0000 & & & & & & & \\
\hline comcol $_{\text {od }}$ & 0.2044 & -0.2285 & 1.0000 & & & & & & \\
\hline smctry $y_{\text {od }}$ & 0.3614 & -0.2102 & 0.3254 & 1.0000 & & & & & \\
\hline contig $_{o d}$ & 0.3060 & -0.2918 & 0.1697 & 0.3883 & 1.0000 & & & & \\
\hline $\operatorname{lang}_{\text {od }}$ & 0.1277 & -0.2347 & 0.5648 & 0.1870 & 0.1726 & 1.0000 & & & \\
\hline ethni_lang od & 0.0843 & -0.1186 & 0.3987 & 0.1183 & 0.1357 & 0.7263 & 1.0000 & & \\
\hline$G D P_{o t}$ & -0.0809 & 0.2190 & -0.1007 & -0.0352 & -0.0383 & -0.0833 & -0.0528 & 1.0000 & \\
\hline$G D P_{d t}$ & -0.0142 & 0.0370 & -0.0179 & -0.0065 & -0.0080 & -0.0221 & -0.0175 & 0.1880 & 1.0000 \\
\hline
\end{tabular}




\section{Appendix C}

\begin{tabular}{|c|c|c|c|c|c|}
\hline $\begin{array}{c}\text { SIC } \\
\text { Industry }\end{array}$ & $\begin{array}{c}\text { SITC } \\
\text { Industry }\end{array}$ & Low-Transport Cost Industries & $\begin{array}{c}\text { Freight } \\
\text { Cost }\end{array}$ & $\begin{array}{c}\text { Plant } \\
\text { Size }\end{array}$ & $\sigma$ \\
\hline 334 & 68 & Secondary nonferrous metals & 0.014 & 35.1 & 6.7 \\
\hline $382,384,385$ & 87 & Measuring devices, medical instruments & 0.023 & 57.7 & 6.7 \\
\hline 3554 & 725 & Paper industries machinery & 0.024 & 54.7 & 8.5 \\
\hline 237 & 848 & Fur goods & 0.027 & 4.7 & 5.6 \\
\hline 387 & 885 & Watches and clocks & 0.027 & 42.2 & 8.1 \\
\hline 354 & 736,737 & Metalworking machinery & 0.027 & 22.2 & 8.1 \\
\hline 3792 & 786 & Trailers and campers & 0.027 & 50.3 & 7.1 \\
\hline 3552 & 724 & Textile machinery & 0.028 & 29.6 & 8.5 \\
\hline 358 & 741 & Refrigeration machinery & 0.030 & 77.6 & 7.0 \\
\hline 393 & 898 & Musical instruments & 0.030 & 26.5 & 4.9 \\
\hline 353 & 723 & Construction machinery & 0.035 & 53.8 & 8.5 \\
\hline 352 & 721 & Farm machinery & 0.035 & 48.6 & 8.5 \\
\hline 395 & 895 & Pens, pencils, and office supplies & 0.035 & 28.5 & 4.9 \\
\hline
\end{tabular}

\begin{tabular}{cccccc}
\multicolumn{7}{c}{ High-Transport Cost Industries } \\
\hline 2621,2631 & 641 & Paper and paperboard & 0.058 & 359.5 & 4.3 \\
332 & 671,672 & Iron and steel founded products & 0.062 & 104.3 & 3.5 \\
3315 & 677 & Steel wire and related products & 0.066 & 70.8 & 3.5 \\
281 & 52 & Inorganic chemicals & 0.070 & 72.4 & 1.4 \\
322 & 665 & Glassware and Glass Containers & 0.070 & 125.9 & 2.7 \\
3317 & 678 & Steel pipes and tubes & 0.079 & 101.7 & 3.5 \\
3312 & 674 & Blast furnace and steel mill products & 0.079 & 786.2 & 3.5 \\
325 & 662 & Structural clay products & 0.158 & 56.6 & 2.7 \\
\hline
\end{tabular}

Notes: Freight costs equal (c.i.f. industry imports/customs value of industry imports)-1, and are based on U.S. imports in 1990 from Feenstra (1996). Plant size is industry average workers per establishment, based on the 1992 U.S. Census of Manufacturers. $\sigma$ is the OLS estimate of the elasticity of substitution in Hummels (1999) for the corresponding two-digit SITC industry. All estimates are statistically significant at the $5 \%$ level. See his paper for more details on the estimation technique.

Figure 3: Industry Average Plant Size and Freight Costs

\section{Appendix D}

Table (11) presents individual gains by agreements considering all the different steps of integration (e.g. UDAO- $>$ UDEAO- $>$ CEAO which are ancestors of the current WAEMU). The big picture of these results is presented in the text by aggregating gains and by showing that these gains are correlated with the network of countries. 
Table 11: Individual country gains induced by RTAs on the whole period

\begin{tabular}{|c|c|c|}
\hline Country & Creation (million of Pounds) & $\%$ of Total Trade \\
\hline BENIN & 2139.462 & $27.678 \%$ \\
\hline BURKINA FASO & 1247.393 & $19.898 \%$ \\
\hline CÔTE D'IVOIRE & 37102.187 & $28.585 \%$ \\
\hline GUINEA-BISSAU & 422.191 & $19.318 \%$ \\
\hline MALI & 552.326 & $9.544 \%$ \\
\hline MAURITANIA & 607.734 & $2.634 \%$ \\
\hline NIGER & 1594.244 & $20.731 \%$ \\
\hline SENEGAL & 12731.912 & $53.233 \%$ \\
\hline TOGO & 7222.807 & $52.513 \%$ \\
\hline CAMEROON & 3633.084 & $5.345 \%$ \\
\hline CENTRAL AFRICAN.R & 26.998 & $0.703 \%$ \\
\hline CHAD & 122.664 & $0.622 \%$ \\
\hline CONGO-BRAZAVILLE & 486.380 & $0.572 \%$ \\
\hline EQUATORIAL GUINEA & 507.971 & $0.682 \%$ \\
\hline GABON & 373.999 & $0.421 \%$ \\
\hline CAPE VERDE & 11.353 & $1.919 \%$ \\
\hline GAMBIA & 123.203 & $5.405 \%$ \\
\hline GHANA & 3241.532 & $5.502 \%$ \\
\hline GUINEA & 336.126 & $1.480 \%$ \\
\hline LIBERIA & 328.760 & $1.195 \%$ \\
\hline NIGERIA & 40282.345 & $5.046 \%$ \\
\hline SIERRA LEONE & 93.481 & $1.101 \%$ \\
\hline BURUNDI & 202.121 & $8.023 \%$ \\
\hline COMOROS & 7.602 & $1.127 \%$ \\
\hline EGYPT & 12000.928 & $4.408 \%$ \\
\hline ERITREA & 17.368 & $1.451 \%$ \\
\hline ETHIOPIA & 1364.629 & $7.237 \%$ \\
\hline KENYA & 26635.335 & $42.001 \%$ \\
\hline LESOTHO & 841.222 & $13.572 \%$ \\
\hline LIBYA & 1075.592 & $0.234 \%$ \\
\hline MADAGASCAR & 831.207 & $4.103 \%$ \\
\hline MALAWI & 3310.990 & $26.334 \%$ \\
\hline MAURITUS & 3447.369 & $10.207 \%$ \\
\hline MOZAMBIQUE & 7675.941 & $26.916 \%$ \\
\hline NAMIBIA & 2581.165 & $11.867 \%$ \\
\hline RWANDA & 324.470 & $8.680 \%$ \\
\hline SOMALIA & 40.201 & $0.636 \%$ \\
\hline SUDAN & 1493.702 & $1.674 \%$ \\
\hline SWAZILAND & 5837.870 & $41.037 \%$ \\
\hline TANZANIA & 4104.096 & $14.732 \%$ \\
\hline UGANDA & 4384.025 & $26.077 \%$ \\
\hline ZAMBIA & 12762.736 & $25.219 \%$ \\
\hline ZIMBABWE & 13926.581 & $35.141 \%$ \\
\hline ANGOLA & 11423.655 & $3.061 \%$ \\
\hline BOTSWANA & 1815.810 & $5.906 \%$ \\
\hline
\end{tabular}




\section{References}

[5] Anderson, J.E. and Y. Yotov, 2010. "The Changing Incidence of Geography." American Economic Review, 100 (5): 2157-86.

[8] Baier, S. L. and J H. Bergstrand, 2007. "Do Free Trade Agreements Actually Increase Members' International Trade?" Journal of International Economics, 71 (1) : 72-95.

[10] Berhens, K., C. Gaigné, G. Ottaviano and J. F. Thisse, 2006. "Is Remoteness a Locational Disadvantage?" Journal of Economic Geography, 6 (3) : 347-368.

[1] Bouet, A., D. Laborde Debucquet and D. Martimort, 2014. "Two-tier asymmetric information as a motive for trade, trade policies, and inefficient trade agreements." IFPRI discussion papers 1383, International Food Policy Research Institute.

[12] Brülhart, M., 2009. "An Account of Global Intra-industry Trade, 1962-2006." The World Economy, 32 (3) : 401-459, 03.

[13] Candau, F. and S. Jean, 2009. "What are EU Trade Preferences Worth for SubSaharan Africa and other Developing Countries ?" In Trade reference Erosion : Measurement and Policy, World Bank and Palgrave-Macmillian series.

[14] Carrère, C., 2004. "African Regional Agreements: Their Impact on Trade with or without Currency Unions." Journal of African Economies, 13 (2) : 199-239.

[15] Cipollina, M. and L. Salvatici, 2010. "Reciprocal Trade Agreements in Gravity Models : A Meta-Analysis." Review of International Economics, 18 (1): 68-80.

[16] Costinot, A. et al, 2017. "The More We Die, The More We Sell? A Simple Test of the Home-Market Effect."NBER Working Paper No. w22538

[2] Crozet, M. and F. Trionfetti (2008).'Trade costs and the Home Market Effect." Journal of International Economics, 76 : 309-321.

[17] Dekle, R., J. Eaton, and S. Kortum, 2008. "Global Rebalancing with Gravity: Measuring the Burden of Adjustment." IMF Staff Papers, 55(3), 511-540.

[3] De Melo, J. and Y. Tsikata, 2015. "Regional integration in Africa: challenges and prospects," in C. Monga and J. Lin (eds.), The Oxford Handbook of Africa and Economics, Volume 2: Policies and Practices. Oxford: Oxford University Press. 
[19] De Sousa, J., T. Mayer and S. Zignago, 2012. "Market Access in Global and Regional Trade." Regional Science and Urban Economics, 46 (6) : 1037-1052.

[24] Disdier, C. A. and K. Head, 2008. "The Puzzling Persistence of the Distance Effect on Bilateral Trade." Review of Economics and Statistics, 90 (1) : 37-48.

[25] Egger, P., 2000. "A Note on the Proper Econometric Specification of the Gravity Equation." Economics Letters 66, 25-31.

[27] Fally, T., 2015. "Structural Gravity and Fixed Effects." Journal of International Economics, 97 (1): 7685.

[28] Foroutan, F., and L. Prichett, 1993. "Intra-sub-Saharan African Trade: Is There Too Little?" Journal of African Economies, 2 : 74- 105.

[31] Fouquin, M. and J. Hugot, 2016. "Two Centuries of Bilateral Trade and Gravity Data : 1827-2014." CEPII Document de travail 2016-14 Mai.

[4] Hanson G.H. and C. Xiang, 2004. "The Home-Market Effect and Bilateral Trade Patterns." American Economic Review, Vol.94, no.4 : 1108-1129.

[5] Harris, C. D., 1954. "The market as a factor in the localization of industry in the United Sates." Annals of the Association of American Geographers, 44(4), 315-348.

[32] Head, K. and T. Mayer, 2014. "Gravity Equations : Workhorse, Toolkit, and Cookbook." in Gopinath, G, E. Helpman and K. Rogoff (eds), Chapter 3.

[6] Hoekman B and D Njinkeu, 2017. Integrating Africa: Some Trade Policy Research Priorities and Challenges. N 43 Robert Schuman Centre for Advanced Studies, Global Governance Programme-277

[33] Khol T., S. Brakman and H. Garretsen, 2016. "Do Trade Agreements Stimulate International Trade Differently ? Evidence from 296 Trade Agreements." The World Economy, 39 (1) : 97-131.

[34] Krugman, P., 1980. "Scale Economies, Product Differentiation, and the Pattern of Trade." American Economic Review, 70 (5) : 950-959. 
[35] Krugman, P., 1993. "The Hub Effect: or, Threeness in Interregional Trade." Edited by Wilfred J. Ethier, University of Pennsylvania, Elhanan Helpman, Harvard University, Massachusetts, J. Peter Neary, University College Dublin, Chapter 3 : $29-37$.

[40] Magee, C. S. P., 2008. "New Measures of Trade Creation and Trade Diversion." Journal of International Economics, 75 (2) : 349-362.

[42] Mossay, P. and T. Tabuchi, 2015. "Preferential Trade Agreements Harm Third Countries." Economic Journal, Royal Economic Society, 125 (589) : 1964-1985.

[43] Ossa, R., 2011. "A 'New Trade' Theory of GATT/WTO Negotiations." Journal of Political Economy, 119 (1) : 122-152.

[44] Puga, D. and A. J. Venables, 1997. "Preferential Trading Arrangements and Industrial Location." Journal of International Economics, 43 (3-4) : 347-368.

[45] Rodrik, D., 1998. "Trade Policy and Economic Performance in Sub-Saharan Africa." NBER Working Paper No. 6562.

[7] Rodrik, D., 2018. "What Do Trade Agreements Really Do ?" Journal Of Economic Perspectives, 23(2) : 73-90.

[46] Sachs, J.D. and A.M. Warner, 1997. "Sources of slow growth in African economies." Journal of African Economies 6 (3): 335-376.

[48] Silva, S. and S. Tenreyro, 2006. "The Log of Gravity." Review of Economics and Statistics, $88: 641-658$.

[50] Subramanian, A. and N. Tamirisa, 2001. "Africa's Trade Revisited." IMF Working Paper No. 01/33, International Monetary Fund, Washington, DC. 